\title{
EFFECT OF NITROUS OXIDE ANAESTHESIA ON HOMOCYSTINE EXCRETION
}

\author{
Joan C. Bevan, D.S. Rosenblatt, Carol L. Clow and Valerie A. Chapman
}

\section{ABSTRACT}

\begin{abstract}
Research into the biotransformation of inhaled general anaesthetic agents, including nitrous oxide, has led to a better understanding of the underlying mechanisms. It is now known that nitrous oxide can react chemically with vitamin $\mathrm{B}_{12}$, oxidizing $\mathrm{Cob}$ (I)alamin to the inactive $\mathrm{Cob}(\mathrm{III})$ alamin form. Clinical and experimental evidence in mammals has confirmed that nitrous oxide toxicity, with symptoms suggestive of clinical vitamin $B_{12}$ deficiency, occurs on exposure to nitrous oxide in a way which is dose and time related and reversible on withdrawal of the nitrous oxide. Nitrous oxide depresses the two known vitamin $\mathbf{B}_{12}$ dependent enzymes methylmalonyl CoA mutase and methionine synthetase by inactivation of their coenzymes adenosylcobalamin and methylcobalamin respectively. Methionine synthetase catalyses the conversion of homocystine to methionine, so interference with this reaction should cause methionine to be depleted and homocysteine to accumulate and to be excreted in the urine. We postulated that the detection of homocystinuria would therefore be an early indicator of nitrous oxide toxicity. Accordingly, we tested the first urine voided postoperatively of 41 patients undergoing nitrous oxide anaesthesia ( 17 neonates exposed to 50-66 per cent nitrous oxide for a mean of $3.0 \mathrm{hr}$, and 24 older patients exposed to 66 per cent nitrous oxide for a mean of $7.2 \mathrm{hr}$ ). None of these patients demonstrated homocystinuria.
\end{abstract}

KEY WordS: ANaESTHETICS, gases, nitrous oxide, Toxicity, metabolic, nitrous oxide, cobalamin, homocystine.

DESPITE THE widespread use of nitrous oxide remarkably few side effects have been noticed, and until recently it was thought to be chemically inert and eliminated unchanged from the body. It is now known that nitrous oxide can react chemically with vitamin $B_{12}$ (cobalamin), oxidizing the active $\operatorname{cob}(\mathrm{I})$ alamin to the inactive cob(III)alamin form. ${ }^{1}$ Prolonged nitrous oxide administration to man in the treatment of tetanus has resulted in leucopaenia and megaloblastic

Joan C. Bevan, M.D., DRCOG, FFARCS, Assistant Professor of Anaesthesia, McGill University and Department of Anaesthesia Montreal Children's Hospital; D.S. Rosenblatt, M.D., C.M., Associate Professor of Paediatrics, McGill University and Department of Biochemical Genetics, Montreal Children's Hospital; Carol L. Clow, Lecturer in Paediatrics, McGill University and Department of Biochemical Genetics, Montreal Children's Hospital; Valerie A. Chapman, R.N., Head Nurse, Department of Anaesthesia, Montreal Children's Hospital.

Address for Correspondence: Dr. Joan C. Bevan, Department of Anaesthesia, Montreal Children's Hospital, 2300 Tupper Street, Montreal, Quebec, Canada $\mathrm{H} 3 \mathrm{H} 1 \mathrm{P} 3$. anaemia. ${ }^{2}$ Megaloblastic changes in the bone marrow and abnormalities of the deoxyuridine suppression test, indicating abnormal vitamin $B_{12}$ or folic acid metabolism, have been noted after only 5-12 hours of nitrous oxide for postoperative analgesia. ${ }^{3}$ The development of neuropathies has been ascribed to occupational exposure to nitrous oxide in dentists. ${ }^{4}$ These haematological and neurological symptoms are similar to those of clinical vitamin $B_{12}$ deficiency. The toxicity of nitrous oxide has been confirmed experimentally and it has been demonstrated that the cellular damage in the marrow and blood is dose and time related and reversible following its withdrawal. ${ }^{5-7}$

In mammals there are two enzymes known to be vitamin $B_{12}$ dependent, methionine synthetase (MS) and methylmalonyl CoA mutase (MMCOAM). The activities of these are inhibited to varying degrees during controlled nitrous oxide exposures. MS is suppressed within 30 minutes whilst MMCoAM remains unaffected for several days. ${ }^{8}$ At present bone marrow examination is necessary to show megaloblastic 
changes caused by nitrous oxide toxicity. However, if these metabolic derangements associated with functional vitamin $\mathrm{B}_{12}$ deficiency in man are the same as in the rat, then MS activity will be inhibited early. This enzyme is required for the intracellular conversion of homocystine to methionine, so homocystine would not be converted to methionine. Homocystine concentration should increase and it should be excreted in the urine. Theoretically, the detection of homocystinuria would then provide a simple screening test for nitrous oxide toxicity in our patients.

\section{MeTHODOLOGY}

\section{Patients}

Forty-one surgical patients, free from metabolic disorder or treatment likely to result in bone marrow suppression, were studied. General anaesthesia involved tracheal intubation and intermittent positive pressure ventilation with the administration of 50 or 66 per cent nitrous oxide at normal atmospheric pressure. The dosage of nitrous oxide was constant, the variable factor being the duration of exposure, which was determined by the nature of the operation.

These patients included 17 neonates (mean age 11.2 days, range $12 \mathrm{hr}-4 \mathrm{wk}$ ) exposed to 50-66 per cent nitrous oxide for a mean of $3.0 \mathrm{hr}$ (range 1-6.5 hr), and 24 older children and young adults (mean age $8.9 \mathrm{yr}$, range $6 \mathrm{wk}-23$ yr) having longer exposures to 66 per cent nitrous oxide for a mean of $7.2 \mathrm{hr}$ (range 2$18 \mathrm{hr}$ ).

\section{Detection of Homocystinuria}

The first urine voided after operation was collected either in a collecting bag or from an indwelling catheter. A sample was tested for the presence of homocystine by a simple colorimetric assay using nitroprusside, which reacts chemically with the urinary disulphides cystine and homocystine following their reduction to sulphydryl compounds by cyanide. ${ }^{9}$ Equal volumes of urine and aqueous five per cent sodium cyanide are mixed. After 10 minutes a few drops of nitroprusside reagent are added and the resulting colour is recorded. A magenta colour is produced by a positive test which occurs if the sample contains more than $10 \mathrm{mg} \cdot \mathrm{dl}^{-1}$ cystine or $3 \mathrm{mg} \cdot \mathrm{dl}^{-1}\left(0.12 \mu \mathrm{mol} \cdot \mathrm{ml}^{-1}\right)$ homocystine. Any questionable result was checked on an amino acid analyser.
Results

No homocystinuria was detected in any of these patients.

\section{Discussion}

We have suggested that early nitrous oxide toxicity may be expressed by homocystinuria on the basis of our current knowledge of the biosynthetic pathways involving vitamin $B_{12}$ in mammals. Body cobalamin is mainly in the form of two enzymatically active derivatives, adenosylcobalamin (AdOCbl) and methylcobalamin (MeCbl). Dietary vitamin $\mathrm{B}_{12}$ entering the body cells as hydroxocobalamin (OH-Cbl) contains trivalent cobalt, which undergoes a two-stage reduction to $\mathrm{Cob}(\mathrm{I})$ alamin. This is followed by adenosylation or methylation to produce Ad$\mathrm{OCbl}$ and $\mathrm{MeCbl}$ respectively. AdOCbl acts as coenzyme for methylmalonyl $\mathrm{CoA}$ mutase (MMCOAM) in the isomerization of methylmalonyl $\mathrm{CoA}$ to succinyl $\mathrm{CoA}$, and $\mathrm{MeCbl}$ as coenzyme for methionine synthetase (MS) in the methylation of homocystine to methionine (Figure 1). ${ }^{10}$ Although these reactions are imperfectly understood, recent advances have been made through studies of children suffering from the rare genetically determined errors in cobalamin metabolism. ${ }^{11}$ Total body cobalamin may be normal, but functional deficiency exists due to defective synthesis of these apoenzymes, leading to the excretion of methylmalonic acid (if AdOCbl is deficient) or homocystine (if $\mathrm{MeCbl}$ is deficient). If there is a failure of a

$$
\mathrm{OH}-\mathrm{Cbl}
$$
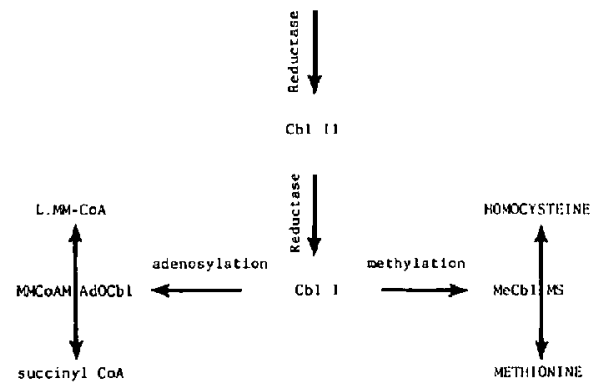

FIGURE 1 Intracellular synthesis of cobalamin coenzymes, adenosyl-cobalamin and methylcobalamin (see text for abbreviations). 
common precursor of both cobalamin coenzymes, then both will appear in the urine. .2,13 $^{2}$

There is no doubt that the cobalamin dependent enzyme MS is inactivated quickly in rats exposed to low concentrations of nitrous oxide for short periods of time. ${ }^{8}$ If the same is true in Inan, then MS activity would be suppressed during the time course of most general anaesthetics. Normally, MS with MeCbl as coenzyme and agent of methyl group transfer catalyses the synthesis of methionine from homocysteine. Interference with this reaction causes methionine to be depleted and homocystine should accumulate and be excreted in the urine. At the same time tetrahydrofolate (THF) will be depleted, creating a folate deficiency in addition to a cobalamin deficiency and aggravating the trend to megaloblastosis.

It was therefore surprising that no homocystinuria was detected in any of our patients. Whilst it is possible that these exposures to nitrous oxide were not long enough to cause toxic effects, some anaesthetics lasted 18 hours. Our test for homocystine is established for use in the diagnosis and control of patients with inherited enzyme defects, although levels of homocystine below $3 \mathrm{mg} \cdot \mathrm{dl}^{-1}$ will not be detected.

We relied to a large extent on animal data in formulating our hypothesis, although we recognize that there may be species differences in the effect of nitrous oxide. Whilst other investigators demonstrated the inhibition of methionine synthetase in mammalian liver by direct enzyme assay, they did not look for homocystine excretion in those experiments. They concluded that methylmalonyl $\mathrm{CoA}$ mutase was unaffected by nitrous oxide exposure when assessed by the urinary excretion of methylmalonic acid. ${ }^{6}$ It was later found that both enzymes inhibited in rats if exposures were long enough, ${ }^{8}$ but no further attempt has been made to correlate the excretion of abnormal metabolites resulting from this inhibition. It seemed that these studies would be valuable to do and we chose to look at the clinical situation first, although we hope to provide additional information from current studies in rats undergoing long-term nitrous oxide exposures. We have failed to provide a simple screening test for nitrous oxide toxicity which could be applied to patients and operating room personnel alike. However we hope that this study has high-lighted the problem of recognizing nitrous oxide toxicity and pointed a way to its solution.

\section{ACKNOWLEDGEMENTS}

The authors wish to thank Dr. M. Whitehead for his advice. This is publication number 81035 of the McGill University-Montreal Children's Hospital Research Institute.

\section{REFERENCES}

1. Banks, R.G.S., Henderson, R.J. \& Pratt, J.M. Reactions of gases in solution. Part III: Some reactions of nutrous oxide with transitionmetal complexes. J. Chem. Soc. (A): 2886 (1968).

2. Lassen, H.C.A., Henriksen, E., Neukirch, F. \& Kristensen, H.S. Treatment of tetanus. Entire bone-marrow depression after prolonged nitrous-oxide anaesthesia. Lancet $1: 527-530$ (1956).

3. Amess, J.A.L., Burman, J.F., Rees, G. M., NANCEKIEVILL, D.G. \& Mollin, D.L. Megaloblastic haemopoiesis in patients receiving nitrous oxide. Lancet 2: 339-342 (1978).

4. Brodsky, J.B., Cohen, E.N., Brown, B.W., WU, M.L. \& WITCHER, C.E. Exposure to nitrous oxide and neurological disease among dental professionals. Anesth. Analg. 60: 297-301 (1981).

5. Kripke, B.J., Talarico, L., Shah, N.K. \& Kelman, A.D. Hematologic reaction to prolonged exposure to nitrous oxide. Anesthesiology 47: 342-348 (1977).

6. Deacon, R., Lumb, M., Perry, J., Chanarin, I., Minty, B., Halsey, M.J. \& Nunn, J.F. Selective inactivation of vitamin $B_{12}$ in rats by nitrous oxide. Lancet 2: 1023-1024 (1978).

7. Scott, J.M., Reed, B., McKenna, B., McGrug, P, McCann, H., O'Sullivan, H., WILSON, P. \& WEIR, D.G. A study of the multiple changes induced in vivo in experimental animals by inactivation vitamin $B_{12}$ using nitrous oxide. Chemistry and Biology of Pteridines, Kisliuk/Brown eds., New York, Elsevier North Holland, pp 335-340 (1979).

8. KONDO, H., OSBORNE, M.L., KOLHOUSE, J.F., Binder, M.J., Podell, E.R., Utley, C.S., ABRAMS, R.S \& ALLEN, R.H. Nitrous oxide has multiple deleterious effects on cobalamin metabolism and causes decreases in activities of both mammalian cobalamin-dependent enzymes in rats. J. Clin. Invest. 67: 1270-1283 (1981).

9. SCRIVER, C.R. \& Rosenberg, L.E. Amino acid metabolism and its disorders. Major problems in clinical pediatrics, X. Philadelphia, W.B. Saunders, p. 137 (1973).

10. Mahoney, M.J. \& Rosenberg, L.E. Inborn errors of cobalamin metabolism. (In) Cobalamin: Biochemistry and Patho-physiology, 1st ed., Babior, B. M., ed., New York, John Wiley pp. 369-402 (1975).

11. Rosenberg, L.E., Lillueqvist, A.-C. \& Hsia, 
Y.E. Methylmalonic aciduria: an inborn error leading to metabolic acidosis, long-chain ketonuria and intermittent hyperglycinemia. N. Eng. J. Med. 278: 1319-1322 (1968).

12. Mudd, S.H., LeVy, H.L. \& Abeles, R.H. A derangement in $\mathbf{B}_{12}$ metabolism leading to homocystinemia, cystathioninemia and methy!- malonicaciduria. Biochem. Biophys. Res. Commun. 35: 121-126 (1969).

13. Goodman, S.L., MoE, P.G., Hammond, K.B. MUdD, S.H. \& UhLENDORF, B.W. Homocystinuria with methylmalonic aciduria: Two cases in a sibship. Biochem. Med. 4:500-515(1970).

RESUME

Grấce aux recherches récentes on comprend mieux maintenant le mécanisme de la biotransformation des agents anesthésiques. On sait que le protoxyde d'azote peut réagir chimiquement avec la vitamine $B_{12}$ en oxydant la $\mathrm{Cob}(\mathrm{I})$ alamine en une forme inactive la Cob(III)alamine. Des études en clinique et en laboratoire ont montré que la toxicité du protoxyde d'azote se manifeste par des symptômes suggestifs' d'une déficience en vitamine $\mathrm{B}_{12}$ et que sa gravité est proportionnelle à la durée d'exposition du sujet ainsi qu'à la concentration du protoxyde d'azote utilisée, et disparait à l'arrêt de son administration. Le protoxyde d'azote déprime l'activité des deux enzymes contrôlees par la vitamine $\mathrm{B}_{12}$, la méthylmalonyl CoA mutase et la métionine synthétase par inactivation de leur coenzymes adénosylcobalamine et méthylcobalamine. La méthionine synthétase catalyse la conversion de l'homocystine à méthionine, de sorte que l'interférence avec cette réaction devrait causer une déplétion de la méthionine et l'accumulation d'homocystine qui sera éventuellement excrétée dans l'urine. Nous avons postulé que la détection d'homocystinurie pourrait être un indicateur de toxicité au protoxyde d'azote. Nous avons donc analysé la première évacuation d'urine post-opératoire de 41 patients sous protoxyde d'azote (17 nouveaux-nés exposés à des concentrations de 50 à 66 pour cent pendant une période moyenne de 3.0 heures et 24 patients plus agés exposés à une concentration de 66 pour cent pour une période moyenne de 7.2 heures). Aucun de ces patients n'a montré d'homocystinurie. 